\title{
A Multi-centre Survey of Acceptability of Newborn Screening for Sickle Cell Disease in Nigeria
}

\author{
Obiageli E. Nnodu ${ }^{1}$, Samuel A. Adegoke ${ }^{2}$, Osita U. Ezenwosu ${ }^{3}$, Ifeoma I. Emodi ${ }^{4}$, Ngozi I. Ugwu ${ }^{5}$, \\ Chinatu N. Ohiaeri ${ }^{6}$, Biobele J. Brown ${ }^{7}$, John A. Olaniyi ${ }^{8}$, Hezekiah Isa ${ }^{9}$, Chinedu C. Okeke ${ }^{10}$, Benard A. \\ Bene ${ }^{11}$, Modupe T. Balogun ${ }^{12}$, Emmanuel O. Okocha ${ }^{13}$, John C. Aneke ${ }^{13}$, Juliana Olufunke J. Lawson ${ }^{14}$, \\ Abjah M. Usman ${ }^{15}$, Ijeoma N. Diaku-Akinwumi ${ }^{16}$, Angela A. Okolo ${ }^{17}$, Yetunde T. Israel-Aina ${ }^{18}$, \\ Mustapha Jamda ${ }^{19}$, Oladapo W. Aworanti ${ }^{20}$, Frédéric B. Piel ${ }^{21}$, Adekunle D. Adekile 22
}

\begin{abstract}
1. Department of Haematology \& Blood Transfusion, University of Abuja, Abuja, Nigeria 2. Department of Paediatrics, Obafemi Awolowo University Hospital , Ile-Ife, Osun State 3. Department of Paediatrics, University of Nigeria Teaching Hospital, Enugu 4. Department of Paediatrics, University of Nigeria Teaching Hospital, Enugu, Nigeria. 5. Department of Haematology \& Blood Transfusion, Federal Teaching Hospital, Abakiliki, Ebonyi State, Nigeria 6. Department of Paediatrics, Federal Medical Centre, Keffi, Nasarawa State, Nigeria 7. Department of Paediatrics, University College Hospital, Ibadan, Nigeria 8. Deaprtment of Haematology, University College Hospital, Ibadan, Nigeria 9. Haematology, Bingham University Teaching Hospital, Jos, Plateau State, Nigeria 10. Department of Haematology \& Blood Transfusion, University of Abuja 11. Non-Communicable Disease Division, Federal Ministry of Health 12. Department of Haematology \& Blood Transfusion, Lagos State University Teaching Hospital, Ikeja, Lagos, Nigeria 13. Department of Haematology, Nnamdi Azikiwe Teaching Hospital, Nnewi , Anambra State, Nigeria 14. Department of Paediatrics, Zankli Medical Centre, Mabushi, Abuja. 15. Department of Haematology, University of Maiduguri Teaching Hospital, Maiduguri, Borno State 16. Department of Paediatrics, Lagos State University Teaching Hospital, Ikeja, Lagos 17. Departmentof Paediatrics, Delta State University Teaching Hospital, Asaba, Delta State 18. Department of Paediatrics, University of Benin, Benin City, Edo State of Nigeria 19. Community Medicine, University of Abuja, Public Health \& Tobacvo Control 20. Department of Haematology, University College Hospital, Ibadan, Nigeria 21. SAHSU, Mrc-Phe Centre for Environment \& Health, School of Public Health, Faculty of Medicine, Imperial College London 22. Department of Paediatrics, Kuwait University
\end{abstract}

$\square$ Corresponding author: Obiageli E. Nnodu, oennodu@gmail.com Disclosures can be found in Additional Information at the end of the article

Received 02/24/2018 Review began 03/02/2018 Review ended 03/16/2018 Published 03/21/2018

\section{(c) Copyright 2018}

Nnodu et al. This is an open access article distributed under the terms of the Creative Commons Attribution License CC-BY 3.0., which permits unrestricted use, distribution, and reproduction in any medium, provided the original author and source are credited.

\section{Abstract \\ Background}

Sickle cell disease (SCD) is a major genetic disease that manifests early in life and may lead to significant morbidities. One of the health care services that have been effective in reducing the burden of SCD in developed countries is newborn screening (NBS) followed by pneumococcal vaccines, penicillin prophylaxis, and hydroxyurea treatment. Yet, in sub-Saharan African countries, where about $75 \%$ of annual affected babies worldwide are born, NBS programmes are largely unavailable. It is not clear whether this is due to technical challenges associated with setting up such programmes, or significant cultural and social barriers to its acceptance in such settings.

\section{Objective}

Our aim was to ascertain the attitudes to and acceptability of NBS in Nigeria among various sociodemographic groups including health professionals, undergraduate students, parents of children with SCD and SCD patients.

\section{Methods}

Data on socio-demographic characteristics, knowledge of SCD and attitude towards NBS were collected using a semi-structured pre-tested questionnaire from April to July 2014 across 15 health institutions and university campuses in Nigeria. Data were collected from 1,301 respondents across Nigeria.

\section{Results}

There was good knowledge of SCD as an inherited blood disorder. Although $86 \%$ of respondents $(n=1,119)$ supported NBS, there was a statistically significant relationship between support for NBS and age $(p=003)$, educational status $(\mathrm{p}=000)$ and religion $(\mathrm{p}=000)$.

\section{Conclusion}

This study suggests that there is a good acceptability of NBS across Nigeria. The main barriers to its use are likely to be financial and practical, rather than social or cultural.

Categories: Genetics, Pediatrics, Public Health 
Keywords: new-born screening, sickle cell disease, acceptability, knowledge and attitude, genetic disease, nigeria, health survey, health care services, health care professionals, undergraduate students

\section{Introduction}

Sickle cell disease (SCD) is a major genetic disease that manifests early in life and may lead to a lifelong illness with complications affecting almost every organ system in the body. The prevalence of sickle haemoglobin is between 20 and 30\% in countries like Nigeria [1], Cameroon, the Democratic Republic of the Congo, Ghana and up to $45 \%$ in parts of Uganda. According to the World Health Organisation (WHO), the majority of children with the most severe form of the disease die before the age of 5 years, usually from an infection or severe blood loss. Therefore, the 63rd World Health Assembly, held in May 2011, adopted a resolution [2,3] calling upon affected countries to strengthen their response to SCD by increasing awareness about the global burden of haemoglobin disorders, promoting equitable access to health services and providing technical support for the prevention and management of the diseases. One program that has been effective in reducing the burden of SCD in developed countries, particularly in the US is newborn screening (NBS) [4,5]. So far, only a few African countries like Ghana, Benin, the Democratic Republic of the Congo and Uganda have offered NBS as pilot projects with external funding, but none has yet managed to scale up to a nation-wide effective screening program [6-10].

Although SCD is a major non-communicable disease (NCD) in Nigeria, with $2 \%$ prevalence in infancy [11], little attention has been paid to its prevention and management until recently. In order to address Nigeria's 90,000+ annual births affected by sickle cell anaemia and the childhood under-five mortality associated with it, the government established six Millennium Development Goals (MDG) sickle cell centres between 2012 and 2013, one in each of the geopolitical zones of the country. Each centre was equipped with one BioRad VARIANT ${ }^{\mathrm{TM}}$ high-performance liquid chromatography (HPLC) machine. The centres were meant to set up NBS and outreach services within the local communities aimed at early detection of individuals affected with SCD, health maintenance and comprehensive care as well as counselling and education of those with sickle cell trait. Almost six years later, the NBS program for SCD has been slow to take off and only the centre in North Central Nigeria has started operation at low capacity.

The acceptability of NBS for most of the country is unknown. Due to previous reluctance of target populations to accept health care services which are meant to benefit them, as was the case with immunization services [12], the Sickle Cell Support Society of Nigeria (SCSSN), which is the umbrella body for experts, patients, NGOs and others with interest in SCD in Nigeria and the Diaspora, conducted an exploratory survey to investigate the knowledge and attitude of different segments of the Nigerian population about SCD and towards different strategies for early diagnosis and reduction in the prevalence and burden of the disease in the country. The specific objectives were to ascertain the knowledge and attitudes of health professionals, parents, undergraduates and SCD patients towards NBS and its acceptability among the study population.

\section{Materials And Methods}

\section{Study design}

This was a multi-centre, cross-sectional assessment of the knowledge and attitude of health professionals, parents of SCD patients, individuals with SCD and undergraduate students towards NBS. A copy of the questionnaire is shown in Appendix 1 to illustrate the choices of answers available.

A multi-stage sampling technique was used to select a mixture of public-private Sickle Cell and Clinical Centres (i.e., newborn screening centres and tertiary health care and other centres affiliated to the SCSSN), in each of the six geopolitical zones of the country. In each centre, individuals with SCD, parents of SCD patients, health care workers, were selected through simple random sampling as they arrive in the clinics. The undergraduate students of the universities affiliated to these centres were selected by cluster sampling technique.

All the categories of respondents were administered the pretested data collection tool. The data collection tool is a semi-structured questionnaire adapted from Wonkam et al. [13]. The questionnaire written in English was designed to collect information from respondents on socio-demographic characteristics, knowledge about SCD, attitudes towards SCD screening policies and SCD-related diagnosis. Data were collected using this questionnaire between April and July 2014 across 15 health institutions and university campuses in Nigeria.

"Knowledge" in this study refers to what the respondents know about the cause of SCD, either as a disease entity inherited from parents, transmitted through contact with SCD patients, or cultural/religious beliefs (e.g., curse/punishments from God, or a dead child that reincarnated in the family).

"Attitude" in the context of this study refers to the perception of the participants, whether NBS should be carried out and, if so, at what time: before marriage, during pregnancy, after the birth of newborn babies or if family members of SCD patients should be screened. 


\section{Cureus}

\section{Ethical issues}

Ethical clearance was obtained from the Health Research Ethics Committee of University of Abuja Teaching Hospital (FCT/UATH/HREC/PR/352) and validated in other research centres as required. The aims and objectives of the study were explained to the respondents verbally. A written consent was obtained from each participant before enrolment in the survey. All identifiers of the respondents were removed from the data collection tool to encourage the participants to give honest responses to them.

\section{Data analysis}

Data collected from all the participating centres were manually entered into a Microsoft Excel database and checked for errors. Socio-demographic characteristics were presented in frequencies and percentages. Awareness of each component of knowledge (e.g., causation, possibility to diagnose in utero, soon after birth and any other time) and attitude towards screening for SCD (including before marriage, during pregnancy, after birth and reasons for each decision; practice of screening for parents of SCD clients) were presented in frequencies and then later cross-tabulated against age, sex, educational status, religion, income, marital status and number of living children. Statistical significance between different groups was established using the Chi-square test with a level of significance set at $p<0.05$. The Likert package in R 3.4.3 was used to visualize the survey results.

\section{Results}

There were 1,301 respondents. 51.6\% (671) of whom were males and 46\% (604) females. Twenty-six respondents (2\%) did not indicate their gender. The mean age was 29 years, age range (19-49) years. The survey included 151 SCD patients (11.6\%), 132 parents of individuals with SCD (10.2\%), 627 undergraduate students (48.2\%), and 24 members of the SCSSN (1.8\%) as described in Table 1. 


\section{Cureus}

\begin{tabular}{|c|c|c|c|c|c|}
\hline \multirow[b]{2}{*}{ Variable } & \multicolumn{5}{|l|}{ n (\%) } \\
\hline & & Female & Male & Missing & Total \\
\hline \multirow[t]{5}{*}{ Age Group } & $<21$ & $84(55.6)$ & $66(43.1)$ & $1(0.7)$ & $151(100)$ \\
\hline & $21-30$ & 331 (42) & 447 (56.7) & $10(1.3)$ & 778 (100) \\
\hline & $31-40$ & $104(51.7)$ & $96(47.8)$ & $1(.5)$ & $201(100)$ \\
\hline & $41-60$ & 55 (66.3) & $24(28.9)$ & $4(4.8)$ & $83(100)$ \\
\hline & $61+$ & 18 (46.2) & $19(48.7)$ & $2(5.1)$ & 39 (100) \\
\hline \multirow[t]{5}{*}{ Marital Status } & Missing & $12(30.8)$ & $19(48.7)$ & 8 (20.5) & 39 (100) \\
\hline & Single & $382(41.0)$ & 537 (57.5) & $15(1.6)$ & 934 (100) \\
\hline & Married & $206(61.7)$ & $120(35.9)$ & $8(24)$ & 334 (100) \\
\hline & Separated & $10(58.8)$ & 7 (41.2) & 0 & $17(100)$ \\
\hline & Missing & 6 (37.5) & 7 (43.7) & 3 (18.7) & $16(100)$ \\
\hline \multirow[t]{6}{*}{ Religion } & Roman Catholic & $147(49.8)$ & 140 (47.5) & $8(2.7)$ & $295(100)$ \\
\hline & Protestant & $129(45.9)$ & $146(52)$ & $6(2.1)$ & $281(100)$ \\
\hline & Pentecostal & 191 (45.11) & $230(54.3)$ & $3(0.7)$ & $424(100)$ \\
\hline & Muslim & $105(46.5)$ & 117 (51.8) & $4(1.7)$ & $226(100)$ \\
\hline & Traditional & $15(46.8)$ & $16(50)$ & $1(3.1)$ & $32(100)$ \\
\hline & Missing & 17 (93.5) & 22 (51.2) & $4(9.3)$ & $43(100)$ \\
\hline \multirow[t]{5}{*}{ Level of Education } & No Education & $10(66.6)$ & 5 (33.3) & 0 & $15(100)$ \\
\hline & Adult/Qur'anic/Primary & $11(84.6)$ & $2(15.4)$ & 0 & $13(100)$ \\
\hline & Secondary & $111(53.4)$ & $94(45.2)$ & 3 & $208(100)$ \\
\hline & Tertiary & $460(44.4)$ & $555(53.6)$ & 20 & $1035(100)$ \\
\hline & Missing & $12(40)$ & $15(50)$ & $3(10)$ & 30 (100) \\
\hline
\end{tabular}

TABLE 1: Socio-demographic characteristics of respondents $(n=1,301)$.

Overall, there was good knowledge of SCD as an inherited blood disorder (79.4\%). 84.3\% of respondents were aware that the disease could be inherited from both parents. Forty-six individuals (3.5\%) were aware of and disclosed their sickle cell trait status as AS/AC. 73.4\% of respondents were aware of NBS. 67.3\% were aware that SCD can be diagnosed before birth (prenatal diagnosis) and $84.0 \%$ believed that SCD can be diagnosed at any time in the life of a person or during pregnancy. Figure 1 illustrates both the knowledge of SCD among survey respondents and significant differences in the knowledge of SCD by gender. $86.1 \%$ of respondents conceptually supported NBS. The form of SCD screening considered most acceptable was before marriage (95.7\%) while the least acceptable was prenatal diagnosis $(73.8 \%)$. The screening of family members and all pregnant women was also considered acceptable by $84 \%$ and $81.3 \%$, respectively. 


\section{Cureus}

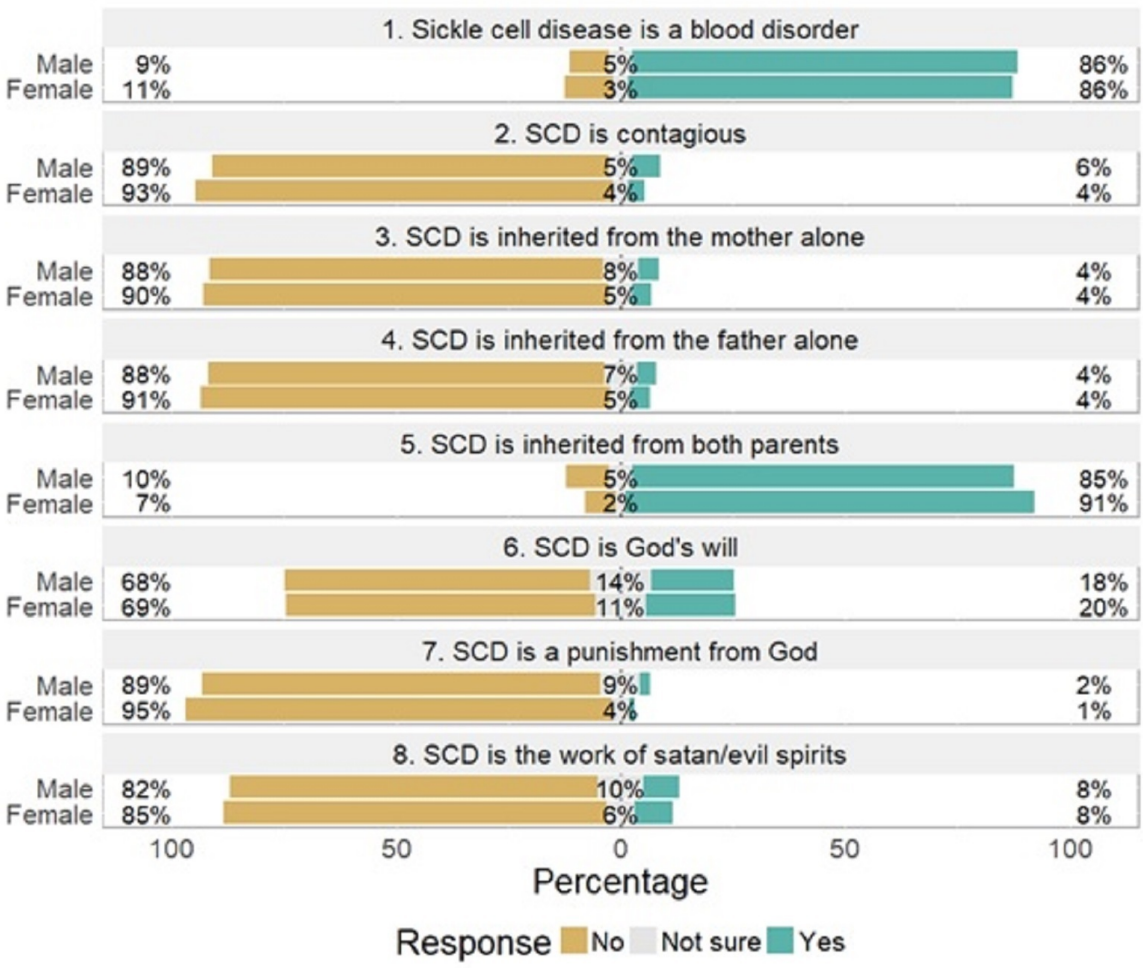

\section{FIGURE 1: Knowledge of sickle cell disease among survey respondents}

by gender.

SCD: Sickle cell disease.

A total of 1,119 (86.1\%) respondents supported NBS. The most acceptable form of SCD screening was that before marriage $(1,246$, i.e. $95.7 \%)$ while the least acceptable was prenatal diagnosis $(961$, i.e. $73.8 \%)$. The screening of family members and all pregnant women was also acceptable by 1,098 (84\%) and 1,057 (81.3\%), respectively.

Cross-tabulating the support for NBS against gender, $90 \%$ of females supported NBS against $88 \%$ of male respondents (Figure 2). NBS was supported by at least $79 \%$ of respondents in all age groups, with a maximum acceptability in those aged 21-30 (90.6\%). There was a statistically significant difference in support for NBS among those with tertiary education, secondary and adult/Qur'anic education $(p=014)$. For marital status, 808 (89.6\%) of respondents that were single, 293 (88\%) of married and 12 (76\%) of those separated/widowed supported NBS. Regarding religion, 271 (92\%) of Roman Catholics, 642 (91\%) of protestants/Pentecostals, $78 \%$ of Muslims and $85 \%$ of traditional religion adherents supported NBS. These findings attest to the achievements of the government and various interest groups which have been carrying out advocacy and community mobilization activities to raise awareness about SCD and its prevention. However, this level of support requires being matched with action through bringing the screening closer home to the newborns in various communities. 


\section{Cureus}

\begin{tabular}{r|rrrr|} 
Male & $1 \%$ & $2 \%$ & $97 \%$ \\
Female & $4 \%$ & $1 \%$ & $95 \%$ \\
\cline { 2 - 5 } & & 2. Would you support screening of babies before & \\
\cline { 3 - 5 } Male & $15 \%$ & birth? & $80 \%$ \\
Female & $16 \%$ & $5 \%$ & $74 \%$
\end{tabular}

3. Would you support screening of all pregnant women for HbS?

\begin{tabular}{r|ccc|} 
Male & $11 \%$ & $6 \%$ & $83 \%$ \\
\hline
\end{tabular}

4. Would you support screening of newborn babies

\begin{tabular}{r|ccc|}
\multicolumn{4}{|c}{ 4. Would you support screening of newborn babies } \\
for SCD?
\end{tabular}

5. Would you support screening of family members

\begin{tabular}{|c|c|c|c|c|c|}
\hline \multirow{3}{*}{$\begin{array}{r}\text { Male } \\
\text { Female }\end{array}$} & \multicolumn{5}{|c|}{$\begin{array}{l}\text { 5. Would you support screening of family members } \\
\text { of patients with SCD? }\end{array}$} \\
\hline & $\begin{array}{l}7 \% \\
8 \%\end{array}$ & & $\begin{array}{l}5 \% \\
4 \%\end{array}$ & & $\begin{array}{l}88 \% \\
88 \%\end{array}$ \\
\hline & 100 & 50 & $\begin{array}{l}0 \\
\text { ent }\end{array}$ & 50 & 100 \\
\hline
\end{tabular}

Response $\square$ No Not sure $\square$ Yes

\section{FIGURE 2: Attitudes towards genetic screening among survey} respondents by gender.

SCD: Sickle cell disease.

Regional differences in support for NBS are shown in Figure 3. There was a statistically significant relationship between support for NBS and age, educational status, religion and category of respondents. Health care providers and individuals with SCD had the highest support for NBS $(p=0.000)$. There was a statistically significant difference $(\mathrm{p}=0.079)$ between acceptability among the young $(21-30$ years old $)$ and the eldest ( $\geqslant 60$ year old). More singles supported NBS compared to married respondents although it was not significant $(p=0.059)$. Similar levels of acceptance among educational levels were observed but there was a statistically significant difference between educated respondents and those with no education $(\mathrm{p}=0.001)$. Muslims reported lowest levels of acceptance when compared with Pentecostals, and other religious groups $(\mathrm{p}=0.01)$.

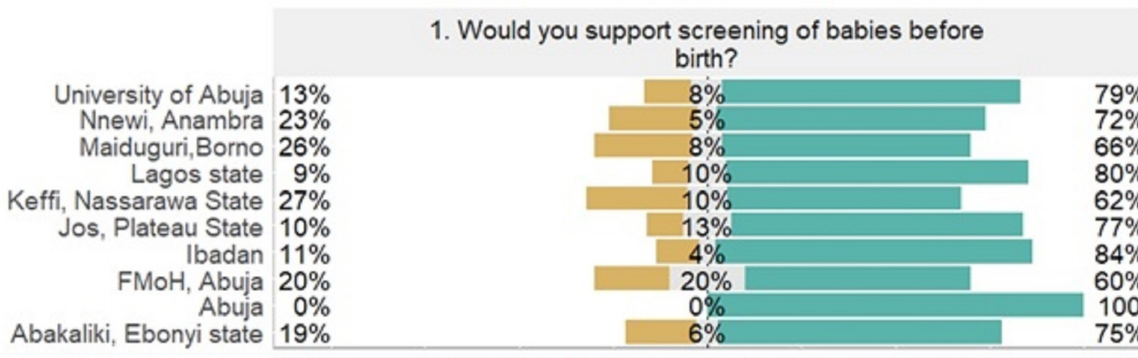

2. Would you support screening of newborn babies

\begin{tabular}{l|l} 
University of Abuja & $2 \%$
\end{tabular} Nnewi, Anambra $11 \%$ Maiduguri,Borno $8 \%$ Lagos state $8 \%$ Keffi, Nassarawa State $19 \%$ Jos, Plateau State $2 \%$ Ibadan $1 \%$ FMoH, Abuja $8 \%$ Abuja $0 \%$

Abakaliki, Ebonyi state $\quad 5 \%$ 100 Percentage for SCD?

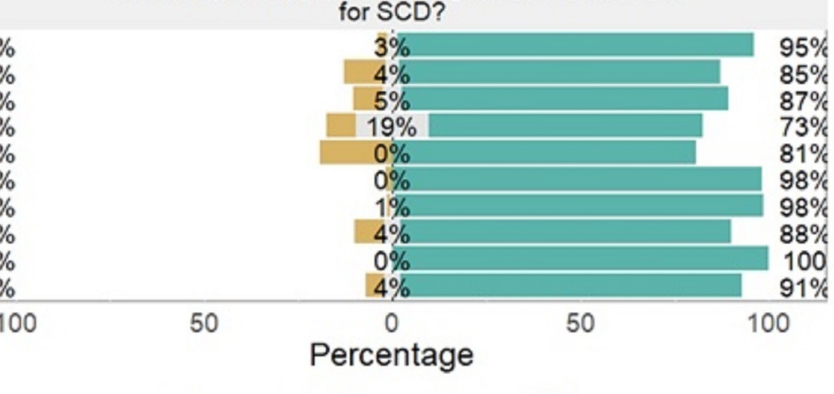

Response $\square$ No Not sure $\square$ Yes

FIGURE 3: Differences between the regional centres included in the 


\section{Cureus}

survey.

SCD: Sickle cell disease.

There was a statistically significant relationship between support for NBS and age, educational status, religion and category of respondents. Thus the variables that were statistically significant following bivariate analysis were tested using the multiple regressions model for significance. Health care providers and individuals with SCD had the highest support for NBS $(\mathrm{p}=0.000)$. The younger age group, 20-21 year old, had the highest support for NBS while the least support was from persons aged 60 years and above $(\mathrm{p}=$ 0.079 ). More singles supported NBS compared to married respondents although it was not significant ( $\mathrm{p}=$ 0.059). There were similar levels of acceptance among educational levels but there was a statistically significant difference between educated respondents and those with no education $(\mathrm{p}=0.0014)$. Muslims reported lowest levels of acceptance when compared with Pentecostals, and other religious groups $(\mathrm{p}=$ 0.01). These are shown in Table 2.

\begin{tabular}{|c|c|c|c|c|c|c|}
\hline Variable & & Do Not Support & Support & Chi-square & p-Value & Remarks \\
\hline \multirow{2}{*}{ Gender } & Male & 40 & 577 & \multirow{2}{*}{$1: 81$} & \multirow{2}{*}{0.398} & \multirow{2}{*}{ NS } \\
\hline & Female & 33 & 519 & & & \\
\hline \multirow{5}{*}{ Age Group } & $<21$ & 5 & 127 & & & \\
\hline & $21-30$ & \multirow{2}{*}{54} & \multirow{2}{*}{856} & & & \\
\hline & $31-40$ & & & & & \\
\hline & $41-60$ & 9 & 69 & \multirow{2}{*}{23.46} & \multirow{2}{*}{0.003} & \multirow{2}{*}{ Significant } \\
\hline & $>60$ & 4 & 34 & & & \\
\hline \multirow{4}{*}{ Education } & Nil & & & \multirow{4}{*}{33.09} & \multirow{4}{*}{0.000} & \multirow{4}{*}{ Significant } \\
\hline & Adult/Quranic & 3 & 8 & & & \\
\hline & Secondary & 14 & 174 & & & \\
\hline & Tertiary & 54 & 897 & & & \\
\hline \multirow{5}{*}{ Religion } & Muslim & 18 & 173 & \multirow{5}{*}{35.91} & \multirow{5}{*}{0.000} & \multirow{5}{*}{ Significant } \\
\hline & Pentecostal & 20 & 379 & & & \\
\hline & Protestant & 11 & 251 & & & \\
\hline & Catholics & 19 & 253 & & & \\
\hline & Traditional & 2 & 26 & & & \\
\hline \multirow{4}{*}{ Category } & Health Care Worker & 0 & 14 & \multirow{4}{*}{8.73} & \multirow{4}{*}{0.001} & \multirow{4}{*}{ Significant } \\
\hline & Parent of SCD Child & 11 & 113 & & & \\
\hline & Undergraduate Student & 6 & 135 & & & \\
\hline & SCD Patient & 33 & 554 & & & \\
\hline
\end{tabular}

TABLE 2: Relationship between support for NBS and selected socio-demographic characteristics. NBS: Newborn screening; NS: Not significant; SCD: Sickle cell disease.

\section{Discussion}

The key public health message from this study is the good acceptability of NBS (86.1\%) across the majority of groups analysed. The Nigerian effort to establish universal newborn screening failed despite the huge investment by the government because the logistics of sample movement for NBS was not matched with funds, there was attrition of trained staff from the zonal centres which did not take ownership of the program by including equipment maintenance costs and consumables for the NBS in their recurrent expenditure. Therefore the reason for poor implementation of NBS on a national scale with full utilisation of 
installed equipment is not due to non-acceptance by the population but possibly due to the high cost of purchase of reagents to run the tests, which costs about $\$ 20$ per test in a country where the minimum wage is about $\$ 60$ per month. This may be applicable to other African countries which have relied on external funding for the various pilot NBS projects which have been executed so far $[6,7,9,10,14]$. The recent development of low-cost rapid point-of-care devices could potentially considerably reduce the costs of NBS in such settings. Additionally, the NBS centres are located in tertiary health care centres, while the majority of Nigerians access health care services at the primary and secondary services rather than the tertiary centres which have longer waiting times and higher cost.

Females and young adults were the most in support of NBS at $90.0 \%$ and $90.6 \%$, respectively. More healthcare providers supported NBS compared to the uneducated. The greater, though non-significant support by young adults, is encouraging since they are in the reproductive age range, thus more likely to practice it. Muslims had the least support to NBS which is likely related to Islamic teaching. Though this was not addressed in the study, Islamic teaching supports acceptance of "genotype" since abortion for SCD is not acceptable. Thus there is a need to access adherents of Islam even before marriage, otherwise, it would be more challenging to intervene afterward. Currently there is some effort at mass mobilization and sensitization activities with advocacy to religious leaders to request for the "genotype" of couples who intend to be joined in marriages, there is a poor uptake of premarital counselling among marriages conducted according to Islamic laws relative to Church weddings where premarital counselling and tests including haemoglobin "genotype" tests are pre-requisites to conducting weddings. As interest in premarital counselling and screening in this population grows, the quality and the source of procurement of "genotype" tests need to be substantiated among faithful adherents of both religious groups [15].

There is some knowledge gap about the possibility of newborn screening among parents with SCD children and in the other groups but once people became aware of it in question 17 of the survey instrument, they gave their support. Since NBS programs rely on public trust, this knowledge gap must be adequately addressed not only at all levels of healthcare but with a functional inter-sectoral collaboration, especially with the mass media. It is for this reason that the SCSSN has incorporated the training of program officers in media houses as part of their activities to increase awareness about SCD and to sensitize the public on the benefits of interventions such as NBS in our country. The newborn screening programme for Nigeria, designed as "spoke and hub" type in which the centres receive samples from the peripheral facilities within each geo-political zones for screening, was found to be inefficient as a result of sustaining the logistics involved. Although the integration of non-communicable disease care including SCD into the primary health care had been done by the government of Nigeria, such integration did not take into account newborn screening tests at that level perhaps due to the available technology for NBS then. The healthcare workers at primary health care were not sensitized on newborn screening as a means of improving child survival. However, with the advent of point-of-care screening tests, once health care workers at primary health care levels are trained, screening can be made routine for all newborns in Nigeria through integration into routine immunization services. This will remove the problem of logistics that have stalled the efficient screenings of newborns at the sickle cell centres. A model of evidence-based interventions for the control of SCD [16], which integrates NBS into existing public health systems such as immunization programs and the Midwives Services Scheme within the Primary Health Care System, has been articulated as a means of making the government sickle cell centres more operational.

A key advantage of this study is the large sample size of 1,301 respondents including various categories of respondents across a wide geopolitical and ethnic distribution in the country compared to more localised studies reported by other workers $[13,17,18]$. A key limitation of our study is that there might have been a bias in the respondents because some of them were attending a healthcare facility or were affiliated with higher educational institutions. The acceptability of NBS might be lower to remote populations or the poorest who would not attend such a facility.

\section{Conclusions}

Majority of respondents $(1,119 ; 86.1 \%)$ supported newborn screening. This is encouraging in view of the planned implementation of interventions at community level aimed at reducing the burden of SCD in Nigeria. However, the study also shows that more awareness needs to be created among those with less education and in some religious groups in order to increase the level of acceptance across all segments of the society.

\section{Appendices}

\section{Questionnaire}

Survey of the Attitudes of Health Professionals, Parents, Undergraduates and Individuals Affected by Sickle Cell Disease towards Prenatal Diagnosis and Newborn Screening in Nigeria.

\section{Preamble}

Sickle cell disease (SCD) is inherited; it manifests early in the life of affected individuals. It usually progresses as a chronic ailment with periods of relative good health punctuated by sudden illness and bone 


\section{Cureus}

pains (crises). Individuals with the disease vary in the way the illness progresses even in the same family. Over time, complications may occur which affect almost every organ system in the body. This places a burden on individuals and their families. The Sickle Cell Support Society of Nigeria is conducting a survey to investigate the knowledge and attitude of different segments of the Nigerian populace about SCD and towards different strategies for early diagnosis and reduction in the prevalence of the disease in the country. We will greatly appreciate it if you could spare some of your precious time to answer the following questions.

Finally, we wish to assure you that under no circumstance would we divulge your responses to anyone.

\section{Consent}

Please indicate if you would like to participate in our study. Yes No...............

Are you a:

1. Health care worker: Member of NSCDA Doctor.

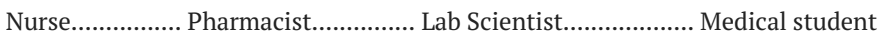

2. Person affected with sickle cell disorder? Yes............ No

3. Parent of an SCD patient

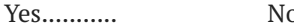

4. Undergraduate student

Yes.........

5. Individual with SCD

Yes.......

Address of

Respondent.

Tel.

Date of birth

For parents of children with SCD and individuals with the disease: Age at diagnosis/Year of diagnosis.

S/N Questions

Remarks

Socio-Demographic Data

Gender

2. Female

Age (years):
1. Less than 20
2. $21-30$
3. $31-40$
4. $41-50$
5. $51-60$
6. $\quad 61-70 \quad 7$ $70+$
1. Father
2. Mother
3. Guardian
4. Individual with sickle cell disorder
5. Student
6. Health care worker
7.

Others

Marital status
1. Single
2. Married
3. Separated
4. Widowed

5. Divorced

Marriage type

5

1. Monogamous 2. Polygamous 


\section{Cureus}

Religion:

1. Roman Catholic

2. Protestant (Orthodox-Anglican, Methodist, Baptist, etc.)

3. Pentecostal

4. Muslim

5. Traditional Religion

6. None

\section{Level of Education}

1. No Education

2. Adult and Quranic education

3. Primary Including (02)

7

4. Junior Secondary

5. Senior Secondary

6. Polytechnic including SRN

7. University education

Approximate amount of income per month:

1. Less than 50,000

8

2. $51,000-150,000$

3. $151,00-500,000$

4. $>500,000$

Occupational status:
1. Student
2. Unemployed
3. Employed in Public Sector
4. Employed in Private Sector

5. Retired

6. Employed Full time

7. Employed part-time

(All except students)

Occupational status

1. White collar worker (professional or technical, manager, administrators, sale workers, clerical workers)

10

2. Blue collar (craft and kindred workers, operatives)

3. Farmer

Family History (Pedigree)

1. Ethnic Group/Tribe

11

2. Number of children or affected siblings with SCD Living. Dead.

3. Genotype of other children/siblings (Normal.

Known...

Unknown.

For Parents /Patients

4. Number of other relatives affected with SCA Sickle Cell Trait i.e. AS.

Respondent's Knowledge of SCD. Please indicate Yes or No to the following statements Sickle cell disease is -
1. Blood disorder: Yes No..............Not Sure
2. Contagious Yes No .Not sure
3. Is inherited from mother alone Yes...........................Not sure............
4. Is inherited from father alone Yes............ No............Not sure
5. Is inherited from both parents Yes
No............Not sure
6. Is God's will?
Yes.......... No............Not sure
7. Is punishment from God?
Yes....... No. Not sure
8. Is the work of Satan/evil spirits? Yes .No...........Not sure
9. A person with sickle cell disease in a family is a dead child from the family with sickle cell

12 


\section{Cureus}

disease that reincarnated (came back to the family)

Are you married? 1. Yes 2. No How many children do you have?
1. One
2. Two
3. Three
4. Four
5. Five
6. More than 5

If No proceed to $Q 17$

14

If you are married, are you living under the same roof with your partner/spouse?Yes

No

Were you aware of the possibility of having a child with SCD before marriage?

1. Yes

2. No

Q15-16 for parents of affected children

Would you have liked to receive genetic counselling about sickle cell disease before marriage?

1. Yes 2. No 3. Not sure

17 Attitude towards screening

Are you aware that sickle cell disease can be diagnosed at these periods

1. In the prenatal period i.e. before a baby is born

2. Soon after birth (newborn screening)

Yes................ No.................
Yes................. No..................
Yes................. No..................

3. At any other time in a person's life

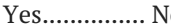

Screening policy (Would you support the following?)

1. Screening before marriage

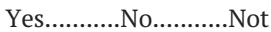

sure

2. Screening of babies before they are born

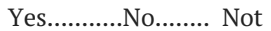
sure

3. Screening of all pregnant women for sickle haemoglobin $\quad$ Yes..........................Not

18 sure

4. Screening of newborn babies for sickle cell disease Yes...........No............Not sure

5. Screening of family members of patients with sickle cell disease Yes...........No...........Not sure.

\section{Prenatal diagnosis}

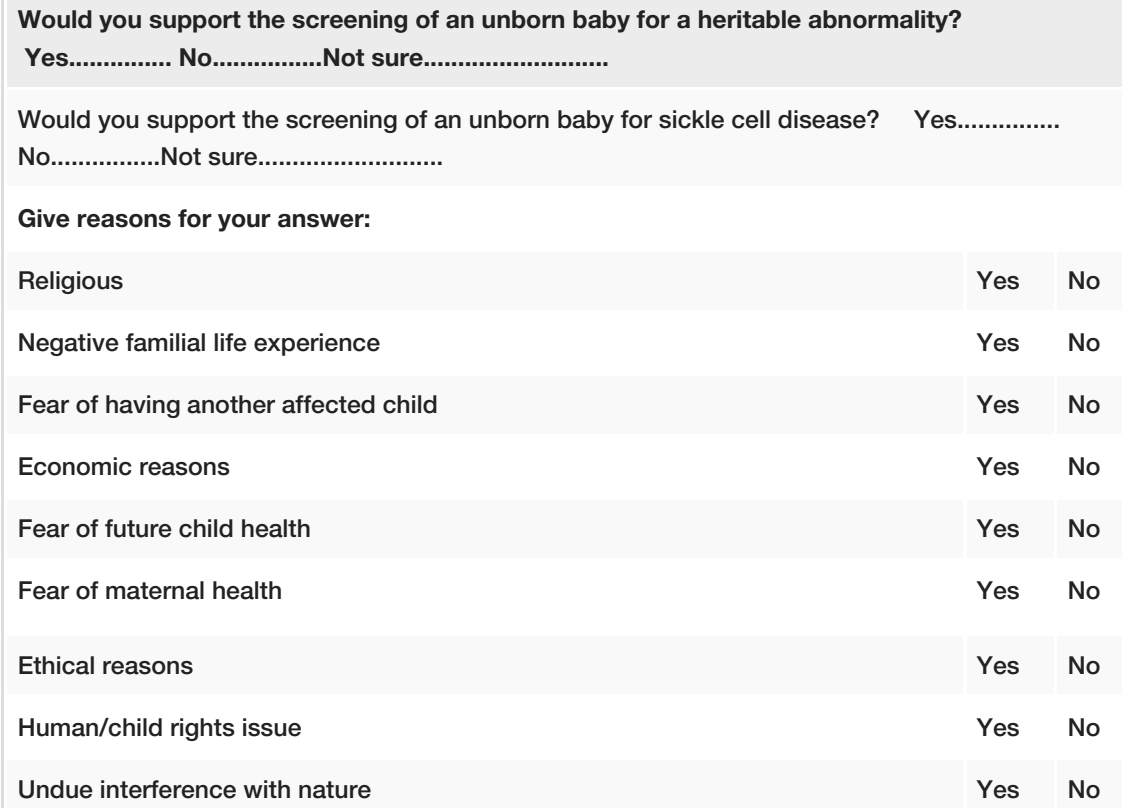




\section{Cureus}

Fear of losing the baby

Attitude towards termination of pregnancy for an unborn baby with sickle cell disease

20

TABLE 3: Questionnaire for the survey.

Fear of maternal health

Ethical reasons

Human/child rights issue

Undue interference with nature

Belief in the right to live with SCD

Having sickle cell disease is not so bad

Having sickle cell disease is not hopeless

These days there is hope of cure
Do you support abortion in general? Yes........No..........Not sure..................

Do you support aborting a child with sickle cell disease? Yes..... No...... Not sure............

It would be against God

Negative family life experience

Fear to have another affected child

Economic reasons

Fear of future child health
Yes No

Yes No

Yes No

Yes No

Yes No

Yes No

Yes No

Yes No

Yes No

Yes No

Yes No

Yes No

Yes No

\section{Additional Information \\ Disclosures}

Human subjects: Consent was obtained by all participants in this study. University of Abuja Teaching Hospital Health Research Ethics Committee issued approval Ref FCT/UATH/HREC/PR/352 of 13/3/2014. Ethical approval for this study was received from the University of Abuja Teaching Hospital, Gwagwalada, Federal Capital Territory, Nigeria. (Ref FCT/UATH/HREC/PR/352 of 13/3/2014). Animal subjects: All authors have confirmed that this study did not involve animal subjects or tissue. Conflicts of interest: In compliance with the ICMJE uniform disclosure form, all authors declare the following: Payment/services info: All authors have declared that no financial support was received from any organization for the submitted work. Financial relationships: All authors have declared that they have no financial relationships at present or within the previous three years with any organizations that might have an interest in the submitted work. Other relationships: All authors have declared that there are no other relationships or activities that could appear to have influenced the submitted work.

\section{References}

1. Piel FB, Patil AP, Howes RE, et al.: Global epidemiology of sickle haemoglobin in neonates: a contemporary geostatistical model-based map and population estimates. Lancet. 2013, 381:142-151. 10.1016/S01406736(12)61229-X

2. Sickle-cell disease: a strategy for the WHO African region. (2010). Accessed: March 2, 2018: http://www.afro.who.int/sites/default/files/2017-06/afr_rc60_8.pdf.

3. United Nations General Assembly Resolution 63/237: recognition of sickle-cell anaemia as a public health problem. (2009). Accessed: February 24, 2018: http://repository.un.org/bitstream/handle/11176/172628/A_RES_63_237-EN.pdf?sequence=1.

4. Therrell BL, Lloyd-Puryear MA, Eckman JR, Mann MY: Newborn screening for sickle cell diseases in the United States: a review of data spanning 2 decades. Semin Perinatol. 2015, 39:238-251. 10.1053/j.semperi.2015.03.008

5. Streetly A, Sisodia R, Dick M, Latinovic R, Hounsell K, Dormandy E: Evaluation of newborn sickle cell screening programme in England: 2010-2016. Arch Dis Child. 2017, 10.1136/archdischild-2017-313213

6. Ohene-Frempong K, Oduro J, Tetteh H, Nkrumah F: Screening newborns for sickle cell disease in Ghana . 


\section{Cureus}

Pediatrics. 2008, 121:S 120.2. 10.1542/peds.2007-2022uuu

7. Tshilolo L, Aissi LM, Lukusa D, Kinsiama C, Wembonyama S, Gulbis B, Vertongen F: Neonatal screening for sickle cell anaemia in the Democratic Republic of the Congo: experience from a pioneer project on 31,204 newborns. J Clin Pathol. 2009, 62:35-38. 10.1136/jcp.2008.058958

8. Rahimy CM, Gangbo A, Ahouignan G, Adjou R, Deguenon C, Goussanou S, Alihonou E: Effect of a comprehensive clinical care program on disease course in severely ill children with sickle cell anaemia in a sub-Saharan African setting. Blood. 2003, 102:834-838. 10.1182/blood-2002-05-1453

9. Ndeezi G, Kiyaga C, Hernandez AG, et al.: Burden of sickle cell trait and disease in the Uganda Sickle Surveillance Study (US3): a cross-sectional study. Lancet Global Health. 2016, 4:e195-e200. 10.1016/S2214109X(15)00288-0

10. Inusa PB, Daniel Y, Lawson JO, Dada J, Matthews CE, Momi S, Obaro SK: Sickle cell disease screening in Northern Nigeria: the co-existence of B-thalassemia inheritance. Pediatr Ther. 2015, 5:262. 10.4172/21610665.1000262

11. Nigeria Demographic and Health Survey 1999, Nigeria National Population Commission . (2000). Accessed: February 24, 2018: https://dhsprogram.com/pubs/pdf/FR115/FR115.pdf.

12. Ophori EA, Tula MY, Azih AV, Okojie R, Ikpo PE: Current trends of immunization in Nigeria: prospect and challenges. Trop Med Health. 2014, 42:67-75. 10.2149/tmh.2013-13

13. Wonkam A, Njamnshi AK, Mbanya D, Ngogang J, Zameyo C, Angwafo FF: Acceptability of prenatal diagnosis by a sample of parents of sickle cell anemia patients in Cameroon (sub-Saharan Africa). J Genet Couns. 2011, 20:476-485. 10.1007/s10897-011-9372-y

14. McGann PT, Ferris MG, Ramamurthy U, Santos B, de Oliveira V, Bernardino L, Ware RE: A prospective newborn screening and treatment program for sickle cell anaemia in Luanda, Angola. Am J Hematol. 2013, 88:984-989. 10.1002/ajh.23578

15. Thuret I, Sarles J, Merono F, et al.: Neonatal screening for sickle cell disease in France: evaluation of the selective process. J Clin Pathol. 2010, 63:548-551. 10.1136/jcp.2009.068874

16. Nnodu OE: Interventions for the prevention and control of sickle cell disease at primary health care centres in Gwagwalada Area Council of the Federal Capital Territory, Nigeria. Cureus. 2014, 6:e194. 10.7759/cureus.194

17. Odunvbun ME, Okolo AA, Rahimy CM: Newborn screening for sickle cell disease in a Nigerian hospital . Public Health. 2008, 122:1111-1116. 10.1016/j.puhe.2008.01.008

18. Durosinmi MA, Odebiyi AI, Akinola NO, et al.: Acceptability of prenatal diagnosis of sickle cell anaemia by a sample of the Nigerian population. Afr J Med Med Sci. 1997, 26:55-58. 